\title{
Effects of cultivar and harvest days after planting on dry matter yield and nutritive value of teff
}

\author{
Benjamin A Saylor ${ }^{1}$, Doohong Min ${ }^{2 *}$ and Barry J Bradford ${ }^{1}$ \\ ${ }^{1}$ Department of Animal Sciences and Industry, Kansas State University, Manhattan, KS 66506, USA \\ ${ }^{2}$ Department of Agronomy, Kansas State University, Manhattan, KS 66506, USA
}

Received: Dec 29, 2020

Revised: Jan 26, 2021

Accepted: Mar 12, 2021

*Corresponding author

Doohong Min

Department of Agronomy, Kansas

State University, Manhattan, KS 66506,

USA.

Tel: +1-785-532-2292

E-mail: dmin@ksu.edu

Copyright $\odot 2021$ Korean Society of Animal Sciences and Technology.

This is an Open Access article distributed under the terms of the Creative Commons Attribution Non-Commercial License (http:// creativecommons.org/licenses/by$\mathrm{nc} / 4.0 /$ ) which permits unrestricted non-commercial use, distribution, and reproduction in any medium, provided the original work is properly cited.

ORCID

Benjamin A Saylor

https://orcid.org/0000-0002-9117-4537

Doohong Min

https://orcid.org/0000-0002-9404-5175

Barry J Bradford

https://orcid.org/0000-0002-6775-4961

Competing interests

No potential conflict of interest relevant to this article was reported.

Funding sources

Contribution no. 17-332-J from the

Kansas Agriculture Experiment Station.

Partial funding for this work was

provided from the Kansas EPSCoR

Program supported by National

Science Foundation Grant No. EPS-

0903806 and the State of Kansas.

Acknowledgements

The authors would like to thank Byron

Seeds (Rockville, IN) and Allied Seed

\section{Abstract}

One of the most pressing issues facing the dairy industry is drought. In areas where annual precipitation is low, irrigation for growing feed presents the greatest water-utilization challenge for dairy producers. Here, we investigated the effects of cultivar and harvest days after planting (DAP) on dry matter (DM) yield and nutritive value of teff (Eragrostis tef), a warm-season annual grass native to Ethiopia that is well adapted to drought conditions. Eighty pots were blocked by location in a greenhouse and randomly assigned to four teff cultivars (Tiffany, Moxie, Corvallis, and Dessie) and to five harvest times (40,45, 50, 55, or 60 DAP). Cultivars had no effect on DM yield and nutritive value. As harvest time increased from 40 to $60 \mathrm{DAP}$, DM yield and ash-free neutral detergent fiber (aNDFom) concentrations increased, while crude protein (CP) concentrations and in vitro NDF digestibility decreased. To assess carryover effects of time of harvest on yield and nutritive value, two additional cuttings were taken from each pot. Increasing first-cutting harvest time decreased CP concentrations in the second cutting and reduced DM yields in the second and third cutting. Harvesting teff between 45 and 50 DAP best optimized forage yield and nutritive value in the first and subsequent cuttings.

Keywords: Drought, Eragrostis tef, Dry matter yield, Nutritive value

\section{INTRODUCTION}

One of the most pressing issues facing the dairy industry is drought. In the Southwestern and High Plains regions of the United States, where annual precipitation is low, irrigation for growing feed presents the greatest water-utilization challenge for dairy producers. More than $90 \%$ of the water used to support a dairy farm is devoted to producing crops that feed the cattle [1]. While the dairy industry has seen impressive growth in states like Kansas, New Mexico, and Texas, ground water levels in these areas have been decreasing at an alarming rate [2]. As ground water levels drop, some wells are no longer able to provide fields with the intended volume of water. Given the high water demands of crops like alfalfa and corn, and that alfalfa hay and corn silage are the most commonly fed forages in the dairy industry, the sustainability of the dairy industry in the Southwest and High Plains is questionable without an intentional shift toward more water-efficient forage crops.

Water-efficient warm-season forage crops with nutritional profiles aligned to the requirements 
(Macon, $\mathrm{MO}$ ) for the donation of teff used in this trial. Additionally, we would like to thank Michael Stamm of Kansas State University for donating a section of his greenhouse space to this project.

\section{Availability of data and materia} Upon reasonable request, the datasets of this study can be available from the corresponding author.

Authors' contributions

Conceptualization: Saylor BA, Min D, Bradford BJ.

Data curation: Saylor BA, Bradford BJ. Formal analysis: Saylor BA, Bradford BJ. Methodology: Min D, Bradford BJ.

Software: Min D, Bradford BJ.

Validation: Min D, Bradford BJ.

Investigation: Saylor BA, Min D, Bradford BJ. Writing - original draft: Saylor BA, Min D, Bradford BJ.

Writing - review \& editing: Saylor BA, Min D, Bradford BJ.

Ethics approval and consent to participate This article does not require IRB/IACUC approval because there are no human and animal participants. of livestock could prove an attractive alternative to traditional forages like alfalfa and corn silage. Teff (Eragrostis tef) is a warm-season annual grass (C4 physiology) native to Ethiopia that is welladapted to arid conditions. For thousands of years, teff has been used as a grain crop for human consumption [3]. Once introduced to the United States, however, researchers began evaluating teff as a forage crop [4]. In 2018, corn silage and alfalfa yield in Kansas, New Mexico, and Texas averaged 14.8 and 11.4 t of dry matter (DM) per ha, respectively [5]. In comparison, teff has potential to yield $12.4 \mathrm{t}$ of $\mathrm{DM}$ per ha with adequate irrigation and fertilization [4,6,7]. Yield data for teff is scarce, however, and may be biased by limitations in our knowledge of teff management, including management of harvest maturity and how this impacts annual yield.

While teff has potential to fit the needs for forage production in water-stressed regions, very little is currently known about its nutritional characteristics and whether it can support high levels of milk production by dairy cattle. In Ethiopia, because teff is primarily grown as a grain crop, most feeding trials have aimed at improving the nutritive value of low-quality teff straw [8-10]. Additionally, studies that have investigated the quality of teff before it reaches full maturity have reported nutritive values that are highly variable. The crude protein $(\mathrm{CP})$ concentration of teff has been reported to range anywhere from 85 to $215 \mathrm{~g} / \mathrm{kg}$ of $\mathrm{DM}[4,6,7,11]$. The neutral detergent fiber (NDF) concentration, a predictor of intake in ruminants, has been reported to range from 525 to $725 \mathrm{~g} / \mathrm{kg}$ of DM $[4,6,11]$. Due to the extreme variation in reported nutritive values for teff, it is difficult to know at this point if teff is a suitable forage source for high-producing dairy cows. Given that the productivity of a dairy cow is highly dependent on forage nutritive value and digestibility [12], standardized nutrient and digestibility values for teff should be established before the productivity of cows fed teff can be investigated. Because both cultivar and time of harvest play a crucial role in dictating the nutritive value of a given forage, the objective of this study was to investigate the effect of cultivar and harvest days after planting (DAP) on DM yield and nutritive value of teff. We hypothesized that relatively early first harvest would result in ideal nutritive value of the forage while maximizing yield across cuttings.

\section{MATERIALS AND METHODS}

\section{Design and treatments}

This experiment was conducted in a climate-controlled greenhouse space at Kansas State University (Manhattan, KS, USA). Temperature in the designated space ranged from $20^{\circ} \mathrm{C}$ to $31^{\circ} \mathrm{C}$, with an average temperature of $25^{\circ} \mathrm{C}$. Fourteen $\mathrm{h}$ of light $\mathrm{d}^{-1}$ were provided as a combination of both natural and artificial light. Eighty plastic pots $(3.78 \mathrm{~L})$ were blocked by location and randomly assigned to four teff cultivars and five harvest times. The 20 treatment combinations were assigned in replicates of four. The four cultivars used in this study were Corvallis, Dessie, Moxie, and Tiffany, representing the varieties that have been most widely evaluated in North America [13-16]. All four cultivars were commercially available at the start of the study and coated. Although the exact coating used on the seeds is proprietary, most seed coatings consist of a combination of lime to regulate soil $\mathrm{pH}$, fertilizer to direct specific nutrients to the site of seed-soil contact, as well as insecticides and fungicides, held together by a binding agent. Coating grass seeds can both enhance germination and add weight to the seeds for easier and more uniform sowing [17].

Seeds were planted in Metro Mix 360 (Sungro Horticulture, Agawam, MA) at a rate of 30 seeds/pot (equivalent to $16.81 \mathrm{~kg} / \mathrm{ha}$ ) and to an average depth of $0.48 \mathrm{~cm}$. At planting, $0.15 \mathrm{~g}$ of urea (equivalent to $56 \mathrm{~kg} \mathrm{~N} \mathrm{ha}^{-1}$ ) was applied to each pot and the pots were lightly watered with a spray bottle. Pots were watered daily with a spray bottle until the seedlings were strong enough to withstand watering with a hose. Mature plants were watered two to three times per week to 
maintain "well-watered" conditions. An additional $0.15 \mathrm{~g}$ of urea (equivalent to $56 \mathrm{~kg} \mathrm{~N}$ ha ${ }^{-1}$ ) was applied to all pots at $\mathrm{d} 60$ after planting. Pots were harvested at one of the following five times: 40, $45,50,55$, and 60 DAP.

\section{Data and sample collection}

Each pot was harvested at the assigned time. Entire plants were cut with gardening clippers to a height of $10 \mathrm{~cm}$ and top biomass was collected and weighed. To assess the carryover effects of first-cutting harvest time on nutritive values, a second cutting was taken from each pot $30 \mathrm{~d}$ after the first cutting. A third cutting was taken $30 \mathrm{~d}$ after the second cutting. After the third cutting, regrowth was insufficient to justify a fourth cutting.

\section{Analytical techniques}

Harvested samples were placed in paper bags and dried at $55^{\circ} \mathrm{C}$ in a forced-air oven for $72 \mathrm{~h}$. After $24 \mathrm{~h}$ of air equilibration, dried samples were weighed to determine DM yield. Samples were then ground through a 1-mm screen using a Cyclone Sample Mill (UDY, Fort Collins, CO, USA). Concentrations of amylase-treated, ash-free neutral detergent fiber (aNDFom) were determined in the presence of sodium sulfite [18] using an Ankom Fiber Analyzer (ANKOM Technology, Macedon, NY, USA). CP was determined by oxidation and detection of $\mathrm{N}_{2}$ (LECO Analyzer, LECO, St. Joseph, MI, USA), multiplied by 6.25. Concentrations of all nutrients except for DM were expressed as percentages of DM determined by drying at $105^{\circ} \mathrm{C}$ in a forced-air oven for more than 8 h. In vitro NDF digestibility (IVNDFD) was analyzed using a DAISY Incubator (ANKOM Technology). Ground grass samples were placed in filter bags with $25 \mu \mathrm{m}$ porosity (ANKOM Technology) and incubated for $24 \mathrm{~h}$ in rumen fluid collected from a mature Holstein steer fed a 50:50 forage: concentrate diet. Once removed from incubation, samples were dried at $55^{\circ} \mathrm{C}$ and transferred to an Ankom apparatus to determine NDF concentration of the residue. Second- and third-cutting samples were analyzed by Dairy One Forage Testing Laboratory (Dairy One, Ithaca, NY, USA) using identical analytical techniques.

\section{Statistical analysis}

The data were analyzed using JMP (version 10.0, SAS Institute, Cary, NC, USA). An analysis of variance was conducted to analyze how the fixed effects of cultivar, harvest time, and their interaction influenced dependent variables. Independent variables were declared significant at $p<$ 0.05 and means were separated by Tukey's HSD (honestly significant difference) test.

\section{RESULTS AND DISCUSSION}

\section{First cutting}

Plant maturity at harvest is one of the principal factors influencing forage nutritive value and digestibility [19]. With the development of higher-quality and more digestible cultivars, however, plant genetics are playing an increasingly crucial role in determining the overall nutritive value of a given forage. Researchers worldwide have investigated the effect of cultivar on the nutritive value and digestibility of a number of forage types including alfalfa (Medicago sativa) [20], corn silage (Zea mays) [21], sorghum (Sorghum bicolor) [22], tall fescue (Festuca arundinacea) [23], oats (Avena sativa), and vetch (Vicia spp.) [24] to name a few. There are multiple cultivars of teff on the market today; some are better for grain production, others for forage production. Grain types tend to mature earlier than forage types, resulting in lower DM yields and reduced nutritive value [4]. In this experiment, all four cultivars evaluated were bred for forage production. After the first cutting, 
cultivar had no effect $(p>0.30)$ on DM yield, aNDFom, CP, or IVNDFD (Table 1).

Harvest DAP, however, had significant impacts on first-cutting forage yield, nutritive value, and digestibility (Fig. 1). It has been recommended that teff be harvested between 45 and 50 DAP to ensure that plants have adequate reserves for regrowth [4]. In the current study, DM yield increased linearly $(p<0.001)$ from 4.1 to $26.4 \pm 0.45 \mathrm{~g} / \mathrm{pot}$ as time of harvest increased from 40 to $60 \mathrm{DAP}$. Additionally, aNDFom concentration increased $(p<0.001)$ from 517 to $635 \pm 8.1 \mathrm{~g} / \mathrm{kg}$ of DM with increasing DAP and CP decreased linearly $(p<0.001)$ from 287 to $112 \pm 4.9 \mathrm{~g} / \mathrm{kg}$ of DM. As forages mature, nutritive value decreases as photosynthetic products such as glucose are converted to fibrous, structural components [19]. Grasses like teff, as opposed to legumes, have higher structural components such as hemicellulose, cellulose, and lignin in both their leaves and stems. Therefore, the nutritive value of grasses tends to decline more rapidly than that of legumes [19]. In this study, the $\mathrm{CP}$ concentration of first-cutting teff decreased linearly at a rate of $8.8 \mathrm{~g} \mathrm{~kg}^{-1} \mathrm{~d}^{-1}$ (Fig. 2). Similar trends have been seen with bromegrass (Bromus inermis) [25] and sorghum-sudangrass (Sorghum bicolor drummondii) [26]. The average greenhouse temperature $\left(25^{\circ} \mathrm{C}\right)$ could explain the higher-than-expected CP concentration of teff cut at 40 and 45 DAP. Lower temperatures slow the maturation process and the subsequent production of fibrous structural compounds thus improving $\mathrm{CP}$ concentration and overall forage nutritive value [19].

Harvest DAP also had a significant effect on the IVNDFD of first-cutting teff (Fig. 1). As time of harvest increased from 40 to 60 DAP, IVNDFD decreased linearly $(p<0.001)$ at a rate of $9.5 \mathrm{~g}$ $\mathrm{kg}^{-1} \mathrm{~d}^{-1}$ (608 to $412 \pm 10 \mathrm{~g} / \mathrm{kg}$ ). The NDF component of teff, like all forages, is composed primarily of cellulose, hemicellulose, and lignin. Lignin represents the indigestible fraction of NDF [19]. As a plant matures, lignin concentration increases, ultimately decreasing the overall digestibility of the fiber [27]. Other studies have confirmed this trend [25,26]. In a meta-analysis conducted by Oba and Allen [28], it was observed that enhanced forage NDF digestibility increased intake and milk yield of dairy cows. In addition, Oba and Allen [28] found that IVNDFD, specifically, is an accurate predictor of productivity of cows fed a given forage. While the nutrient composition and digestibility of forages grown in a greenhouse are not always the same as those grown in the field,

Table 1. Effect of cultivar on yield, nutritive values, and in vitro digestibility of teff

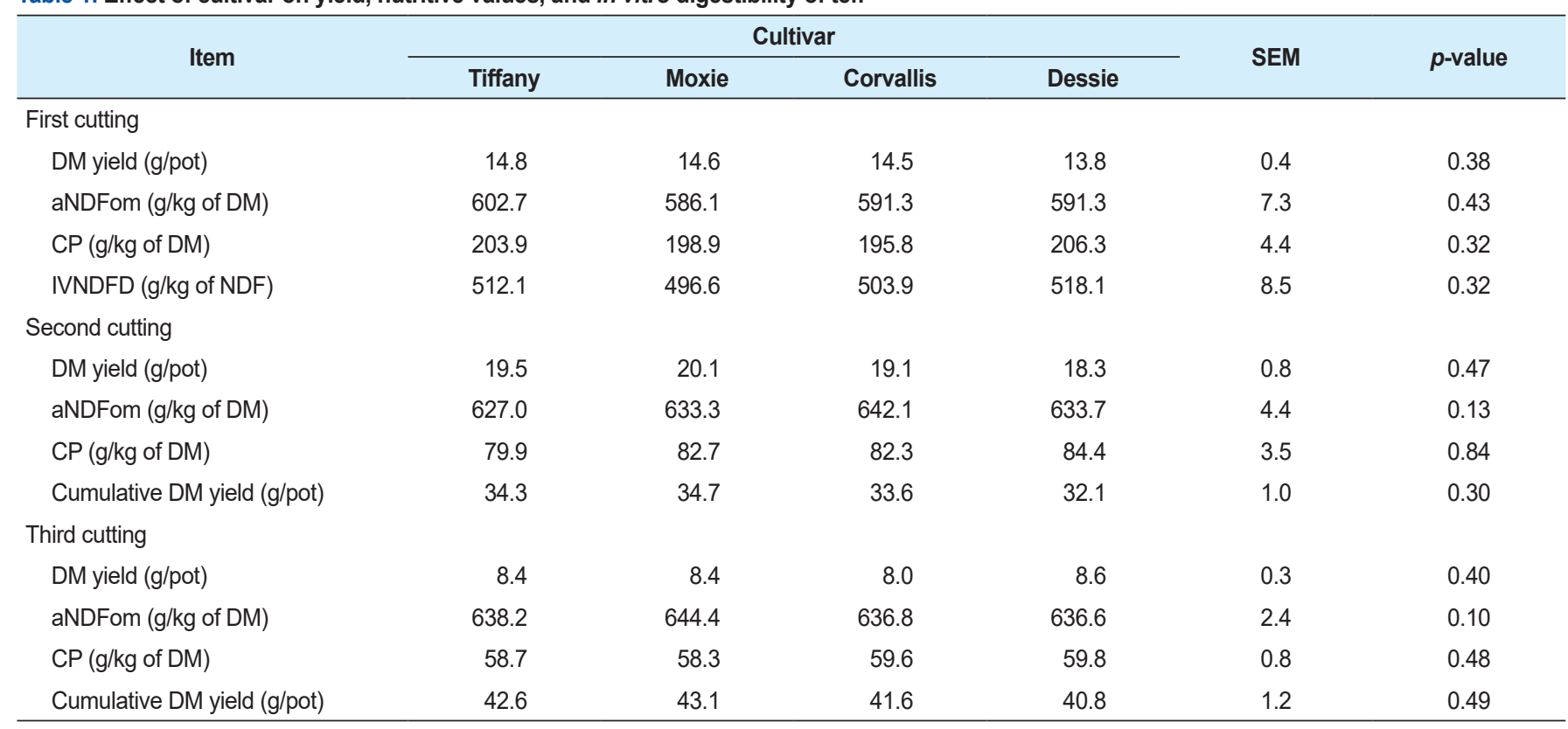

DM, dry matter; aNDFom, ash-free neutral detergent fiber with amylase; CP, crude protein; IVNDFD, in vitro neutral detergent fiber digestibility. 

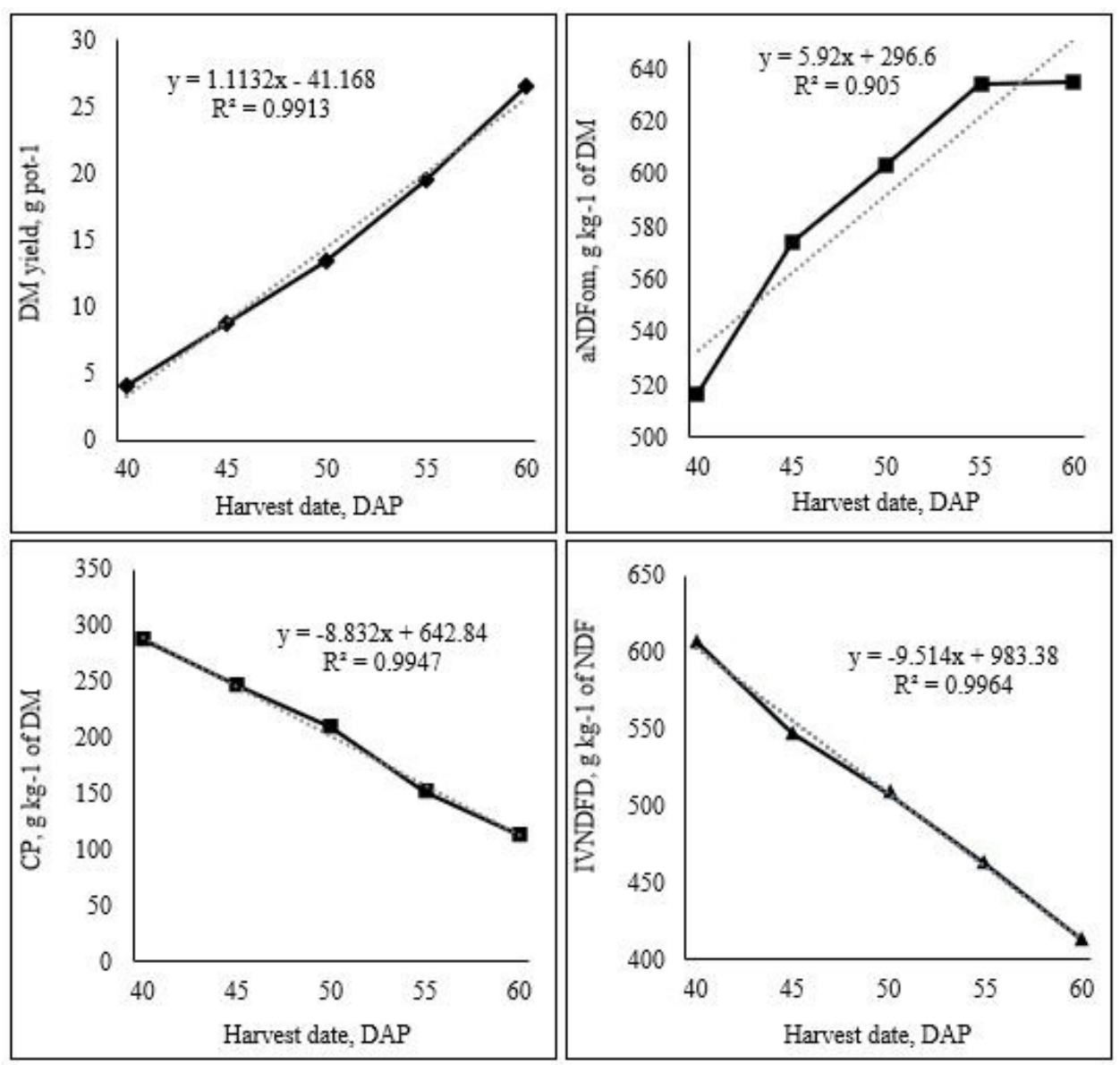

Fig. 1. Effect of harvest time on yield, nutritive values, and digestibility of first-cutting teff grass. Increasing harvest time from 40 to 60 DAP significantly increased DM yield and aNDFom concentration ( $p<$ $0.001)$ but significantly decreased CP concentration and IVNDFD $(p<0.001)$. DAP, days after planting; DM, dry matter; aNDFom, ash-free neutral detergent fiber with amylase; CP, crude protein; IVNDFD, in vitro neutral detergent fiber digestibility.

other studies have used nutritive value and digestibility measurements of greenhouse grown forages as initial estimates of what could be expected in a more practical cultivation scenario [20,29]. No interaction between cultivar and time of cutting was observed for DM yield, nutritive value, and IVNDFD of teff $(p>0.10)$.

\section{Second and third cutting}

After the second cutting, cultivar had no effect $(p=0.47)$ on DM yield, aNDFom concentration $(p=0.13)$, or CP concentration $(p=0.84$, Table 1$)$. Additionally, there was no effect $(p=0.30)$ of cultivar on the cumulative DM yielded from the two cuttings. First-cutting harvest time had a significant effect $(p<0.001)$ on second-cutting DM yield as well as second-cutting aNDFom and CP concentrations (Fig. 2). Dry matter yield after the second cutting decreased from 23.68 to $11.59 \pm 0.91 \mathrm{~g} /$ pot when first-cutting harvest time increased from 40 to $60 \mathrm{DAP}$. We found that second-cutting aNDFom concentration was greatest $(p<0.001)$ in those samples that were first cut at 45 and $50 \mathrm{DAP}$. CP concentration of the second-cutting teff decreased dramatically, from 119.4 to $64.3 \pm 3.2 \mathrm{~g} / \mathrm{kg}$ of DM, when first-cutting harvest time was increased from 40 to $60 \mathrm{DAP}$. No interaction between cultivar and time of first cutting was observed for DM yield, nutritive value, and IVNDFD of second-cutting teff $(p>0.10)$. 


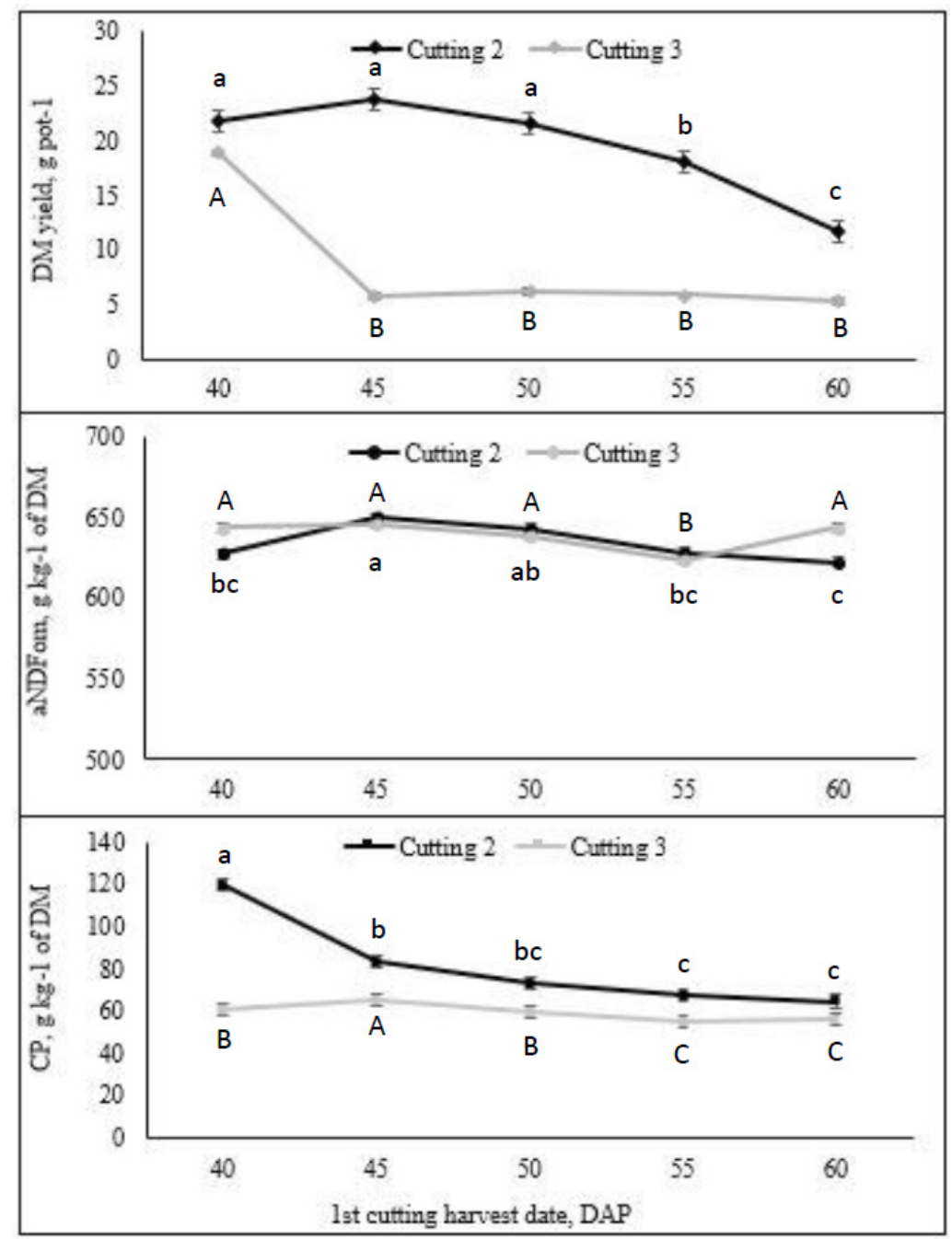

Fig. 2. Effect of first-cutting harvest age on yield, nutritive values, and digestibility of second-and thirdcutting teff grass. For all pots, cutting 2 was taken 30 days after cutting 1 . Cutting 3 was taken 30 days after cutting 2. For cuttings 2 and 3 , first-cutting harvest age was a significant predictor $(p<0.001)$ of DM yield and concentrations of aNDFom and CP. Differences across $1^{\text {st }}$ cutting harvest dates within cutting are denoted by the lack of a shared letter ( $p<0.05$, Tukey's HSD); for clarity, cutting 2 differences are signified with lower-case letters and cutting 3 with upper-case letters. DM, dry matter; aNDFom, ash-free neutral detergent fiber with amylase; CP, crude protein; DAP, days after planting; HSD, honestly significant difference.

After the third cutting, again, cultivar had no effect $(p=0.40)$ on DM yield, aNDFom concentration ( $p=0.10)$, or CP concentration $(p=0.48$, Table 1$)$. Additionally, cultivar had no effect $(p=0.49)$ on the cumulative DM yielded from the three cuttings. Like what was seen after the second cutting, first-cutting harvest time had a significant effect $(p<0.001)$ on third-cutting $\mathrm{DM}$ yield, aNDFom concentration, and CP concentration (Fig. 2). DM yield decreased from 18.70 to $5.24 \pm 0.30 \mathrm{~g} /$ pot when first-cutting harvest time increased from 40 to $60 \mathrm{DAP}$. Third-cutting aNDFom concentration was greatest in samples originally cut at 45 DAP and least in those cut at $55 \mathrm{DAP}(p<0.001)$. CP was greatest in samples originally cut at $45 \mathrm{DAP}$ and least in those cut at 55 DAP. No interaction between cultivar and time of first cutting was observed for DM yield, nutritive value, and IVNDFD of third-cutting teff $(p>0.10)$.

Whereas cultivar had no effect on the agronomic characteristics of teff, first-cutting harvest time played a critical role in influencing yield and nutritive values after the second and third 
cutting. According to Van Soest [19], photosynthetic compounds (i.e., glucose) are either stored or converted to structural material in plants. In a young warm-season grass plant, most of these photosynthetic compounds are stored in the form of starch. Stored root carbohydrates are crucial for regrowth. When grasses are harvested during the late vegetative to early boot stage (40 to 45 DAP), these stored root carbohydrates assist in the regrowth process and improve overall nutritive values. Grasses harvested during the boot to early heading stage (55 to $60 \mathrm{DAP}$ ), however, have already converted a large portion of these photosynthetic compounds to structural compounds. These structural compounds are mostly unavailable to the plant and cannot be used as a source of nutrients [19]. Therefore, root carbohydrates are utilized for regrowth of immature teff, ultimately reducing subsequent yield and protein concentration while increasing the fiber concentration.

Delaying the first cutting from 40 to 60 DAP had a significant impact on the cumulative DM yielded over the course of the trial (Fig. 3). After two cuttings, delaying the first cutting from 40 to $60 \mathrm{DAP}$ significantly increased $(p<0.001)$ total DM yield from 25.76 to $38.00 \pm 1.11 \mathrm{~g} /$ pot. This was most likely due to the fact that the first-cutting yield from plants harvested at 40 and 45 DAP was so low that the cumulative yield for the early-cut plants was still less than that of the latecut plants after two cuttings, despite having a relatively higher second-cutting yield. After three cuttings, however, a first-cutting harvest at 40 DAP yielded significantly more $(p<0.01) \mathrm{DM}$ than a first-cutting harvest at $45 \mathrm{DAP}$ (44.47 vs. $38.15 \pm 1.29 \mathrm{~g} /$ pot, or roughly 26 vs. $22 \mathrm{t} \mathrm{DM} / \mathrm{ha}$ ) and numerically more DM than first-cutting harvests at 50,55, and 60 DAP. After three cuttings, the advantage of harvesting a plant at an earlier maturity during the first cutting significantly outweighed the greater first-cutting yield of a more mature plant. It is important to note that, although yield data collected from the greenhouse is useful for detecting differences among cultivars and first-cutting harvest times, yields observed in field trials do not typically match those observed in a controlled greenhouse setting.

Finally, across all cultivars and harvest times, the second cutting yielded significantly more DM $(p<0.01)$ than the first and third cuttings, and the first cutting yielded significantly more DM $(p<0.001)$ than the third cutting (Table 2). Additionally, aNDFom concentration increased $(p=$

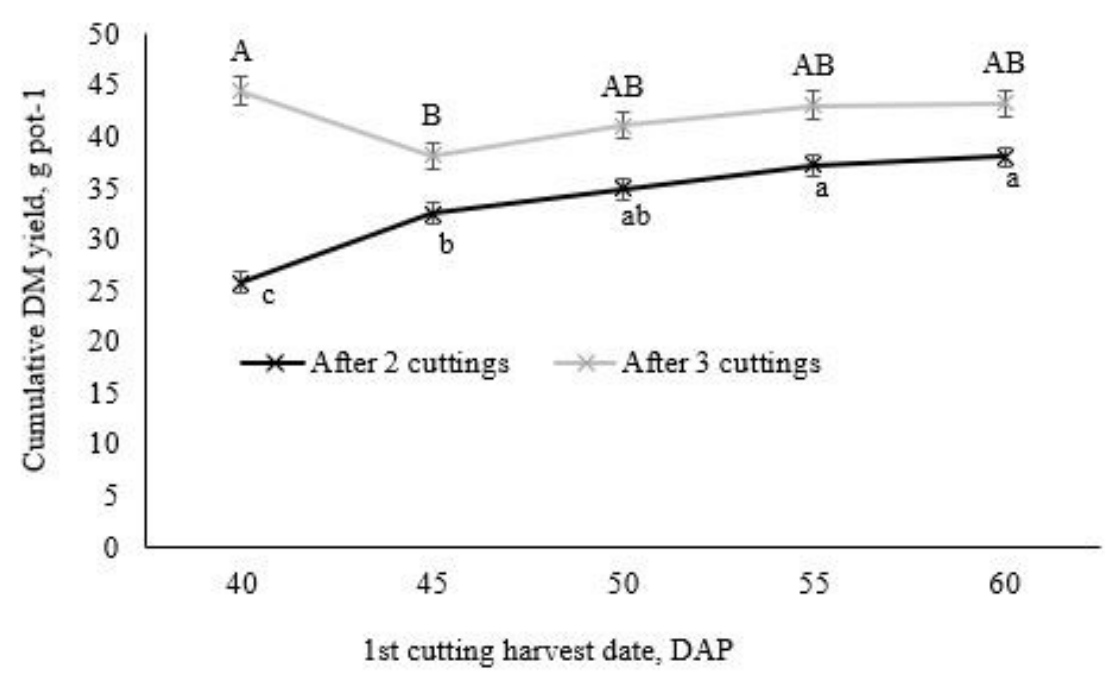

Fig. 3. Effect of first-cutting harvest time on cumulative DM yielded from 3 cuttings. First-cutting harvest time was a significant predictor $(p<0.001)$ of cumulative DM yielded from 3 cuttings. DM, dry matter; DAP, days after planting; aNDFom, ash-free neutral detergent fiber with amylase; CP, crude protein; HSD, honestly significant difference. 
Table 2. Effect of cutting number on yield and nutritive values of teff across all cultivars and first-cutting times

\begin{tabular}{|c|c|c|c|c|c|}
\hline \multirow{2}{*}{ Item } & \multicolumn{3}{|c|}{ Cutting number } & \multirow{2}{*}{ SEM } & \multirow{2}{*}{$p$-value } \\
\hline & 1 & 2 & 3 & & \\
\hline DM yield (g/pot) & $14.6^{\mathrm{b}}$ & $19.3^{\mathrm{a}}$ & $8.3^{c}$ & 0.7 & 0.001 \\
\hline $\mathrm{DM}(\mathrm{g} / \mathrm{kg})$ & $199.6^{c}$ & $267.2^{b}$ & $313.7^{\mathrm{a}}$ & 9.2 & $<0.001$ \\
\hline aNDFom (g/kg of DM) & $594.0^{\mathrm{b}}$ & $634.0^{\mathrm{a}}$ & $638.0^{\mathrm{a}}$ & 4.0 & $<0.001$ \\
\hline $\mathrm{CP}(\mathrm{g} / \mathrm{kg}$ of $\mathrm{DM})$ & $199.7^{\mathrm{a}}$ & $82.3^{\mathrm{b}}$ & $59.0^{\mathrm{b}}$ & 4.5 & $<0.001$ \\
\hline
\end{tabular}

${ }^{a, b}$ Means with different superscripts are significantly different $(p<0.05)$

DM, dry matter; aNDFom, ash-free neutral detergent fiber with amylase; CP, crude protein.

$0.01)$ and CP decreased $(p<0.001)$ when cutting number increased from one to three. Van Soest [19] describes lignification as one of a plant's protective mechanisms against predatory attack or, in this case, a harvest event. As cutting number increases, then it is expected that the concentration of the protective, fibrous component of teff would increase. This is supported by the fact that, as cutting number increased from one to three, forage DM concentration at harvest increased ( $p$ < 0.001) from 199.6 to $313.7 \pm 9.2 \mathrm{~g} / \mathrm{kg}$ (Table 2). Reid et al. [30] reported a similar trend with smooth bromegrass. As cutting number increased from one to four, yield and digestibility tended to decrease while lignin concentration increased. The decrease in the $\mathrm{CP}$ concentration as cutting number increased could be due to both the increase in the fiber portion of the plant as well as the overall depletion of $\mathrm{N}$ and other key nutrients from the soil over time. While additional $\mathrm{N}(0.15 \mathrm{~g}$ of urea) was applied at $\mathrm{d} 60, \mathrm{~N}$ was not applied between the second and third cutting.

\section{CONCLUSION}

Results from this study indicate that, under greenhouse conditions, the first cutting of teff should be harvested at 45 to 50 DAP to optimize forage yield, nutritive value, and digestibility in that cutting and in subsequent cuttings. Overall, the nutrient profile of teff is similar those of other commonly fed grass forages like smooth bromegrass and sorghum-sudangrass. To use teff in the diet of a highproducing dairy cow, maturity at first cutting and soil fertility must be well managed to ensure that the forage provided in the diet is of the highest nutritive value possible.

\section{REFERENCES}

1. Innovation Center for U.S. Dairy. [Internet]. U.S. dairy's environmental footprint. 2013 [cited 2020 Aug 4]. http://www.usdairy.com/ /media/usd/public/dairysenvironmentalfootprint.pdf

2. Cross JA. Change and sustainability issues in America's dairyland. Focus Geogr. 2015;58:17383. https://doi.org/10.1111/foge.12060

3. Mengesha MH. Chemical composition of teff (Eragrostis tef) compared with that of wheat, barley and grain sorghum. Econ Botany. 1966;20:268-73. https://doi.org/10.1007/BF02904277

4. Miller D. Teff grass: crop overview and forage production guide [Internet]. 2011 [cited 2017 Feb 1]. http://teffgrass.com/wp-content/themes/tg/downloads/TeffGrassManagementGuide. pdf

5. USDA [United States Department of Agriculture]. Crop production 2018 summary. Washington, DC: USDA National Agricultural Statistics Service; 2019.

6. Roseberg RJ, Norberg S, Smith J, Charlton B, Rykbost K, Shock C. Yield and quality of teff forage as a function of varying rates of applied irrigation and nitrogen. Klamath Exp Stn. 
2005;119-36.

7. Roseberg RJ, BA Charlton, S Norberg,J Kugler. Yield and forage quality of six teff seed brands grown in three Pacific Northwest environments. In: Klamath Experiment Station 2006 Annual Report. Washington, DC: USDA; 2016. p. 31-45.

8. Bonsi MLK, Osuji PO, Tuah AK, Umunna NN. Intake, digestibility, nitrogen balance and certain rumen characteristics of Ethiopian Menz sheep fed teff straw supplemented with cotton seed cake, dry sesbania, dry leucaena or fresh leucaena. Agrofor Syst. 1995;31:243-56. https:// doi.org/10.1007/BF00712077

9. Bonsi, MLK, Tuah AK, Osuji PO, VI Nsahlai, NN Umunna. The effect of protein supplement source or supply pattern on the intake, digestibility, rumen kinetics, nitrogen utilisation and growth of Ethiopian Menz sheep fed teff straw. Anim Feed Sci Technol. 1996;64:11-25. https://doi.org/10.1016/s0377-8401(96)01048-6

10. Mesfin R, Ledin I. Comparison of feeding urea-treated teff and barley straw based diets with hay based diet to crossbred dairy cows on feed intake, milk yield, milk composition and economic benefits. Livest Res Rural Dev. 2004;16.

11. Young A, Creech E, ZoBell D, Israelsen C, Eun JS. Integrating teff into livestock operations. Logan, UT: Utah State University; 2014. Report No.: AG/Forages/2014-01pr.

12. Allen MS. Relationship between forage quality and dairy cattle production. Anim Feed Sci Technol. 1996;59:51-60. https://doi.org/10.1016/0377-8401(95)00886-1

13. Hunter M, Ketterings QM, Cherney JH, Barney P, Kilcer T, Godwin G. Nitrogen needs of teff managed as forage crop in New York. Forage and Grasslands. 2009;7:1-9. https://doi. org/10.1094/FG-2009-0612-01-RS

14. Hall MH, Cherney JH. Increased teff seeding rates in the northeast region of the United States increases forage yield. Forage and Grazinglands. 2010;8:1-2.

15. Staniar WB, Bussard JR, Repard NM, Hall MH, Burk AO. Voluntary intake and digestibility of teff hay fed to horses.J Anim Sci. 2010;88:3296-303. https://doi.org/10.2527/jas.2009-2668

16. Vinyard JR, Hall JB, Sprinkle JE, Chibisa GE. Effects of maturity at harvest on the nutritive value and ruminal digestion of Eragrostis tef (cv. Moxie) when fed to beef cattle. J Anim Sci. 2018;96:3420-32. https://doi.org/10.1093/jas/sky202

17. Burns J, Bennett B, Rooney K, Walsh J, Hensley J. Coatings for legume and grass seed. In: Proceedings of the 57th South Pasture Forage Crop Improvement Conference; 2002; Athens, GA.

18. Van Soest PJ, Robertson JB, Lewis BA. Methods for dietary fiber, neutral detergent fiber, and nonstarch polysaccharides in relation to animal nutrition.J Dairy Sci. 1991;74:3583-97. https:// doi.org/10.3168/jds.S0022-0302(91)78551-2

19. Van Soest PJ. Nutritional ecology of the ruminant. Corvallis, OR: O \& B Books; 1982.

20. Guo D, Chen F, Wheeler J, Winder J, Selman S, Peterson M, et al. Improvement of in-rumen digestibility of alfalfa forage by genetic manipulation of lignin O-methyltransferases. Transgenic Res. 2001;10:457-64. https://doi.org/10.1023/A:1012278106147

21. Ballard CS, Thomas ED, Tsang DS, Mandebvu P, Sniffen CJ, Endres MI, etal. Effect of corn silage hybrid on dry matter yield, nutrient composition, in vitro digestion, intake by dairy heifers, and milk production by dairy cows. J Dairy Sci. 2001;84:442-52. https://doi.org/10.3168/ jds.S0022-0302(01)74494-3

22. Carmi A, Aharoni Y, Edelstein M, Umiel N, Hagiladi A, Yosef E, et al. Effects of irrigation and plant density on yield, composition and in vitro digestibility of a new forage sorghum variety, Tal, at two maturity stages. Anim Feed Sci Technol. 2006;131:120-32. https://doi.org/10.1016/ j.anifeedsci.2006.02.005

23. Chen L, Auh C, Dowling P, Bell J, Chen F, Hopkins A, et al. Improved forage digestibility of 
tall fescue (Festuca arundinacea) by transgenic down-regulation of cinnamyl alcohol dehydrogenase. Plant Biotechnol J. 2003;1:437-49. https://doi.org/10.1046/j.1467-7652.2003.00040.x

24. Assefa G, Ledin I. Effect of variety, soil type and fertiliser on the establishment, growth, forage yield, quality and voluntary intake by cattle of oats and vetches cultivated in pure stands and mixtures. Anim Feed Sci Technol. 2001;92:95-111. https://doi.org/10.1016/S03778401(01)00242-5

25. Kilcher MR, Troelsen JE. Contribution of stems and leaves to the composition and nutrient content of irrigated bromegrass at different stages of development. Can J Plant Sci. 1973;53:767-71. https://doi.org/10.4141/cjps73-149

26. Ademosum AA, Baumgardt BR, Scholl JM. Evaluation of a sorghum-sudangrass hybrid at varying stages of maturity on the basis of intake, digestibility and chemical composition. J Anim Sci. 1968;27:818-23. https://doi.org/10.2527/jas1968.273818x

27. Jung HG. Forage lignins and their effects on fiber digestibility. Agron J. 1989;81:33-8. https:// doi.org/10.2134/agronj1989.00021962008100010006x

28. Oba M, Allen MS. Evaluation of the importance of the digestibility of neutral detergent fiber from forage: effects on dry matter intake and milk yield of dairy cows. J Dairy Sci. 1999;82:589-96. https://doi.org/10.3168/jds.S0022-0302(99)75271-9

29. Mir Z, Acharya SN, Mir PS, Taylor WG, Zaman MS, Mears GJ, LA Goonewardene. Nutrient composition, in vitro gas production and digestibility of fenugreek (Trigonella foenum-graecum) and alfalfa forages. Can J Anim Sci. 1997;77:119-24.

30. Reid JT, Clark B, Welch JA, Dosza L, Jung GA. Investigation of plant species and maturity stage on forage nutritive value as determined by in vitro digestion techniques. Morgantown, WV: West Virginia Agricultural and Forestry Experiment Station; 1962. USDA Contract No. 12-14-100-4524. 